Summer 2014

\title{
Class Actions, Conflict and the Global Economy
}

Hannah L. Buxbaum

Indiana University Maurer School of Law, hbuxbaum@indiana.edu

Follow this and additional works at: https://www.repository.law.indiana.edu/ijgls

Part of the Civil Law Commons, and the International Law Commons

\section{Recommended Citation}

Buxbaum, Hannah L. (2014) "Class Actions, Conflict and the Global Economy," Indiana Journal of Global Legal Studies: Vol. 21 : Iss. 2 , Article 7.

Available at: https://www.repository.law.indiana.edu/ijgls/vol21/iss2/7

This Lecture is brought to you for free and open access by the Law School Journals at Digital Repository @ Maurer Law. It has been accepted for inclusion in Indiana Journal of Global Legal Studies by an authorized editor of Digital Repository @ Maurer Law. For more information, please contact rvaughan@indiana.edu.

\section{$\Psi$}

JEROME HALL LAW LIBRARY

INDIANA UNIVERSITY

Maurer School of Law
Bloomineton 


\title{
Class Actions, Conflict and the Global Economy ${ }^{1}$
}

\author{
HANNAH L. BUXBAUM ${ }^{*}$
}

The development of the global economy - in the sense of interconnected markets for consumer products, for investment capital, and for labor - has necessitated the development of global regulatory strategies. Such strategies depend on the ability of governments to work together both in coordinating or harmonizing disparate national laws and in establishing cooperative enforcement mechanisms. With respect to the public enforcement of the laws governing economic conduct, this project has been largely successful. Harmonized rules have been developed in a number of areas, creating common standards applicable to the activities of multinational business enterprises. Regulatory agencies such as securities commissions and antitrust authorities work regularly with their counterparts in other countries, ${ }^{2}$ and also participate in multilateral organizations created to facilitate a shared approach to cross-border problems. ${ }^{3}$

With respect to the private enforcement of regulatory law, however, an entirely different picture emerges. Civil lawsuits brought under national regulatory law are a site of conflict, not coordination, among governments. This conflict encompasses disagreement over the extraterritorial application of domestic law, doctrines of adjudicatory jurisdiction, and the use of certain procedural devices in the cross-

1. This essay is a lightly edited and footnoted version of a lecture delivered in April 2011 to inaugurate the John E. Schiller Chair in Legal Ethics at the Indiana University Maurer School of Law. It was previously published in FESTSCHRIFT FÜR ROLF STÜRNER ZUM 70. GeburTstag 1443 (Bruns et al. eds., Mohr Siebeck 2013).

* John E. Schiller Chair in Legal Ethics, Indiana University Maurer School of Law.

2. This work occurs in part pursuant to bilateral or multilateral mutual assistance agreements. In the area of securities enforcement, for instance, over 85 countries are signatories to IOSCO's Multilateral Memorandum of Understanding Concerning Consultation and Cooperation and the Exchange of Information, pursuant to which they regularly cooperate with agencies in other countries. The text of the Memorandum and the list of signatories are available at the IOSCO website, http://www.iosco.org.

3. These include, for example, the International Organization of Securities Commissions, the International Competition Network and the OECD's Task Force on Tax Crimes and Other Crimes.

Indiana Journal of Global Legal Studies Vol. 21 \#2 (Summer 2014)

(C) Indiana University Maurer School of Law 
border context. In addition, the disagreement extends more generally to views of the appropriate role of domestic courts in the international arena.

In previous decades, the primary flashpoint for friction in crossborder civil litigation was the discovery process, as chronicled during the 1980 s in work on the "Justizkonflikt." 4 Today, the flashpoint for such debates seems to be the class action. Disagreement regarding the function and utility of class actions is particularly evident in the U.S.European debate. This essay will focus on that debate, setting out an explanation for the animosity that it has engendered and an argument for quelling that animosity.

Until relatively recently, the United States stood virtually alone in its commitment to ordinary civil litigation as an instrument of economic regulation, and in its support of the procedural devices required to incentivize that litigation. European countries have of course long permitted certain types of collective litigation. One type common to many systems, for instance, is litigation by consumer or trade associations, seeking injunctive relief on behalf of association members. ${ }^{5}$ What these systems have historically not permitted, however, are class actions for monetary damages on the U.S. model: that is, true representative litigation in which one plaintiff can act for, and bind, the rest of the class members. ${ }^{6}$

This legislative landscape has changed significantly in recent years. U.S. courts and legislators have entered a period of retrenchment, cutting back in a variety of ways on the efficacy of class actions. ${ }^{7}$ In

4. See Der Justizkonflikt mit den Vereinigten Staaten von Amerika (Walther J. Habscheid, ed., 1986); Peter Schlosser, Der Justizkonflikt zwischen den USA und Europa (1985).

5. See Christopher Hodges, Western Europe: European Union Legislation, in $D$. Hensler, C. Hodges and M. Tulibacka, The Globalization of Class Actions (The Annals of the American Academy of Political and Social Science, 2009), Vol. 622, at 78 (providing an overview of such mechanisms in different European nations).

6. See generally Hannah L. Buxbaum, Defining the Function and Scope of Group Litigation: The Role of Class Actions for Monetary Damages in the United States, in Europäisches Insolvenzrecht - Kollektiver Rechtsschutz, Peter Gottwald, ed. 2008, at 215.

7. In one recent decision, for example, the Supreme Court adopted a stringent approach to the "commonality" requirement for class certification. Wal-Mart Stores, Inc. v. Dukes, 131 S. Ct. 2541 (2011). In another, it upheld an arbitration clause in a consumer contract that waived the right to pursue class arbitration. AT\&T Mobility LLC v. Concepcion, 131 S. Ct. 1740 (2011). See infra at notes 34-38 and accompanying text for examples of legislative and rule amendments affecting the viability of class actions in the United States. 
Europe, meanwhile, many countries have adopted new procedures for aggregate litigation - either across substantive areas of law, or in connection with some specific regulation, such as a consumer protection law or an antitrust statute. ${ }^{8}$ Additional countries are currently considering such reform. Yet these first steps toward convergence have not yielded increased cooperation and coordination in private enforcement. To the contrary, one finds constant friction between the United States and many European countries - a sharpening, perhaps, of the Justizkonflikt. This is true despite the fact that the United States' historical and current practice with class actions presents a rich resource of information and experience for countries considering their utility.

Whatever one thinks about the successes and the failures of the U.S. class action system - and there are clearly both - it has been in operation for many decades. Information about the procedural rules that govern class actions, the funding models such as contingency fees or fee-shifting arrangements that were developed to encourage class litigation, and, especially, the long history of refinements and adjustments that have been made to the system when it was perceived to be functioning poorly - all are tremendously useful to other systems considering how to create a local model for group litigation. Yet while some effort is being made to examine the United States as a source of information in this sense, the attitude that has emerged in Europe is one of antagonism toward the U.S. class action system. European regulators have characterized the procedural elements supporting U.S. class actions as a "toxic cocktail;"' have warned of the "bogeyman' of US-style excesses;"10 and have invoked the specter of a "litigation

8. For a general overview, see Christopher Hodges, Collective Redress in Europe: The New Model, 29 Civil Just. Q. 370 (2010); Deborah R. Hensler, The Globalization of Class Actions: An Overview, in 622 The Annals of the American Academy of Political and Social Science 7 (D.R. Hensler, C. Hodges and M. Tulibacka eds., 2009), at 13 (noting that at the time of publication "at least eighteen countries had adopted some form of class action" procedure permitting claims to be brought on behalf of absent plaintiffs). The Global Class Action Exchange hosted by the Stanford Law School, available at http://www.globalclassactions.stanford.edu, is a clearinghouse containing up to date legislation and commentary in the area. See also Directorate General for Internal Policies, Overview of Existing Collective Redress Schemes in EU Member States, IP/A/IMCO/NT/2011-16 (July 2011).

9. Meglena Kuneva, Member of the European Commission in charge of Consumer Policy, Speaking Points: Green Paper on Consumer Collective Redress (November 27, 2008), available at http://europa.eu (using that phrase to describe the combination of punitive damages, contingency fees and pre-trial discovery).

10. Neelie Kroes, Member of the European Commission in charge of Competition Policy, Speech: Developments in competition policy since October 2006 - and a look forward into 
culture" that benefits only lawyers and no one else. ${ }^{11}$ The former EU competition commissioner, in an effort to assure listeners that she was not supporting a U.S.-style system, told an audience that she had "left [her] cowboy hat at home;" 12 the former commissioner for consumer protection announced "[w]e are not seeking to import a US style" class system into Europe. Not by the front door - and not ... by the back door." 13 Similar rhetoric is used by national legislators, and finds echoes in some of the legal commentary analyzing the path of procedural reform in European countries. ${ }^{14}$ In sum, a specific antagonism toward the U.S. class action system - not merely a desire to craft an indigenous version of collective actions - has become a backdrop to European law reform.

\section{INTERNAL AND EXTERNAL CAUSES OF ANTAGONISM}

\section{A. The Politics of European Reform}

In my view, part of the explanation for this antagonism toward the U.S. system lies in the process by which procedural reform is being drivien forward in these countries. The motivation for that reform in Europe comes primarily from above, from the European Commission. EU regulatory law now covers an expansive geographic territory, and applies to an ever-increasing level of cross-border trade. At the same time, European regulators face challenges in coordinating the enforcement activities of multiple agencies, as well as mounting funding deficiencies. All of these are reasons to consider stronger private enforcement mechanisms to complement the existing public enforcement structure - and, indeed, the European Commission has

2007 (March 20, 2007), available at http://europa.eu (quoting “A bogeyman abroad?," a March 15, 2007 editorial in the Financial Times).

11. Neelie Kroes, Member of the European Commission in charge of Competition Policy, Speech: Enhancing Actions for Damages for Breach of Competition Rules in Europe (September 22, 2005), available at http://europa.eu; see also Rachael Mulheron, Recent Milestones in Class Actions Reform in England: A Critique and a Proposal, 127 L.Q. Rev. 288, 303 (2011) (quoting the statement by the English Department of Trade and Industry that "we want to avoid exposing business to spurious or vexatious claims or unwittingly create a compensation culture.").

12. Neelie Kroes, Member of the European Commission in charge of Competition Policy, Speech: More private antitrust enforcement through better access to damages: an invitation for an open debate (March 9, 2006), available at http://europa.eu.

13. Kuneva, Speaking Points, supra note 9.

14. See Jeroen S. Kortmann \& Christof R.A. Swaak, The EC White Paper on Antitrust Damage Actions: Why the Member States are (Right to Be) Less Than Enthusiastic, 30 Eur. Comp. L. Rev. 340, 341-42 (2009) (describing various reasons for concerns voiced by governments including those of Denmark, Finland, France, and the Netherlands). 
been pushing hard for stronger private enforcement. ${ }^{15}$ Early in the reform process, the Commission expressed interest in a number of potential procedural reforms intended to spur private enforcement. In particular, it floated the idea of introducing class actions for monetary damages, which would make it economically feasible for plaintiffs to bring claims under regulatory laws, particularly those in which a large number of plaintiffs had suffered small amounts of harm. ${ }^{16}$

While the motivation to introduce mechanisms supporting private enforcement lies primarily at the European Union level, however, such mechanisms must be implemented by individual member states, because they require reform of the procedural rules of national legal systems. ${ }^{17}$ Most European countries are not enthusiastic about that reform, as it would effectuate significant changes within their civil justice systems. In many countries, as one commentator put it, "the fundamental model of litigation is still that of individuals pursuing the protection of individual rights against other individuals," because "only individuals are vested with a right of action for the protection of their own individual substantive rights."18 In systems based on that model, each individual must guide the disposition of his own particular claim, making true representative litigation - in which one lead plaintiff makes decisions for all members of the class - impossible. ${ }^{19}$ Certainly, the "opt out" variant used in the United States - in which a plaintiff

15. For a recent survey of activity by the European Commission, see S.I. Strong, CrossBorder Collective Redress in the European Union: Constitutional Rights in the Face of the Brussels I Regulation, 45 Ariz. St. L.J. (forthcoming 2013), available at http://ssrn.com/abstract=2085501. These developments were driven in part by the 1999 decision of the European Court of Justice in Courage v. Crehan, which emphasized the need to guarantee direct and effective enforcement of rights under the Treaty. Case C453/99, Courage Ltd. v. Bernard Crehan, 2001 E.C.R. 1 (Eng. C.A. 1999).

16. White Paper, Damages Actions for Breach of the EC Antitrust Rules, COM(2008) 165 (2 April 2008); Green Paper, Consumer Collective Redress, COM(2008) 794 (27 November 2008).

17. See Nathalie Jalabert-Doury, Draft Directive on Damage Actions: A 'Coup D'Eclat' Rapidly Set Aside, International Business Journal 2010, Issue 1, 63, at 68-69 (discussing the "confrontations" between European Community competition law and the procedural autonomy of national authorities, and the scope of competence of the European lawmakers).

18. Michele Taruffo, Some Remarks on Group Litigation in Comparative Perspective, 11 Duke J. Comp. \& Int'l L. 405, 415-16 (2001).

19. See generally Duncan Fairgrieve \& Geraint Howells, Collective Redress Procedures - European Debates, 58 Int'l \& Comp. L. Q. 379 (2009) (surveying various procedures in European systems that would constrain the adoption of true representative litigation). 
might be part of a defined class without knowing it, and without realizing that its claim is being disposed - would be impossible. ${ }^{20}$

Thus, although U.S.-style class actions might create benefit, in the form of enhanced regulation within Europe, the adoption of a classaction mechanism would be tremendously disruptive to the culture of civil justice systems at the national level. And, indeed, many European governments resisted immediately the changes proposed by the EU regulators. ${ }^{21}$ The narrative that emerged for that resistance centered on opposition not to collective actions in particular, but to the U.S. class action model in particular. This proved to be a powerful narrative. Reform opponents highlighted the traditional criticisms of the U.S. class action system - for instance, that it promoted vexatious lawsuits and rewarded unscrupulous attorneys - and warned that any adoption of class actions in Europe would diminish the quality of civil justice there. The European Commission regulators in turn positioned their plans within the same narrative. In order to generate support for the reform necessary to enhance private enforcement, they cast any proposed changes as explicitly not on the U.S. model - thus their increasing references to avoiding the "excesses" of the U.S. system. ${ }^{22}$ In this sense, the expressions of hostility toward the U.S. class action had more to do with politics within the European Union than with any relationship to the United States. ${ }^{23}$

20. A handful of European countries have adopted, generally in limited fashion, some version of opt-out procedures. See Overview of Existing Collective Redress Schemes, supra note 8 , at 40 .

21. For a more detailed discussion of this resistance using the example of Germany, see Hannah L. Buxbaum, German Legal Culture and the Globalization of Competition Law: An Historical Perspective on the Expansion of Private Antitrust Enforcement, 23 Berk. J. Int'l L. 474, 489-91 (2005).

22. See Joaquin Almunia, Vice President of the European Commission Responsible for Competition Policy, Speech: Competition Policy: State of Play and Future Outlook, October 21 2010, available at http://europa.eu (stating that while Europe was committed to a stronger collective action framework, it was similarly committed to avoiding "the excesses and drawbacks of the US system."). One commentator noted that "[i]n many countries, the debate over class action adoption is dominated by the concern that, whatever the new procedure looks like, it should not be an "American-style' class action." Deborah R. Hensler, The Future of Mass Litigation: Global Class Actions and Third-Party Litigation Funding, 79 Geo. Wash. L. Rev. 306, 307-08 (2011).

23. See generally Christopher Hodges, Collective Redress in Europe: The New Model, supra note 8, at 372 (discussing the "political consensus" in Europe regarding the U.S. class action system). 


\section{B. The Export of the U.S. Model}

Further explanations for the antagonism toward the U.S. class action, though, are found in the "export" of the American model to Europe. This export has taken place in part by means of multinational class actions in U.S. courts. In these lawsuits, courts have permitted foreign claimants to participate in class actions brought under U.S. regulatory law. For instance, in certain cases arising out of the activities of global price-fixing cartels, U.S. courts certified classes that included not only U.S. purchasers who bought price-fixed goods in U.S. markets, but also foreign purchasers who bought those goods in foreign markets. ${ }^{24}$ Similarly, in certain cases arising out of securities fraud, U.S. courts certified classes that included not only U.S. investors who transacted on U.S. exchanges, but also foreign investors who transacted on foreign ones. ${ }^{25}$ In such cases, the claims - often brought against foreign defendants - were of course subject to American procedural rules. In addition, importantly, the claims of the entire class were governed by American regulatory law. In this manner, the class action was used as a vehicle for applying American law to conduct and transactions that were very closely tied to other countries.

The extraterritorial application of U.S. law in such cases presents a dual concern. First, other countries object that U.S. courts in this manner override other countries' specific regulatory choices, applying U.S. substantive and procedural law - which often differs in significant respects from foreign law - to claims within the purview of foreign regulation. Second, regardless of the particular content of the norms in question, they object that the application of U.S. law in such circumstances violates the sovereignty of other nations. ${ }^{26}$ Although the United States Supreme Court has recently curtailed the application of American regulatory law to claims arising from foreign transactions, ${ }^{27}$ the practice of past decades generated significant foreign opposition. It

24. See Empagran S.A. v. Hoffmann-LaRoche, Ltd., 315 F.3d 338 (D.C. Cir. 2003); Den Norske Stats Oljeselskap As v. Heeremac V.O.F., 241 F.3d 420 (5th Cir. 2001); Kruman v. Christie's Int'l PLC, 284 F.3d 384 (2d Cir. 2002). As discussed further below, recent Supreme Court jurisprudence has since retreated from this position.

25. See, e.g., In re Royal Ahold N.V. Sec. Litig., 351 F.Supp.2d 334 (D. Md. 2004); In re Vivendi Universal, S.A. Sec. Litig., 2004 WL 2375830 (S.D.N.Y. 2004). Again, as discussed below, the U.S. Supreme Court has since retreated from this position.

26. In the cases discussed above, foreign governments filed amicus briefs outlining clearly these objections, characterizing the application of U.S. law in such circumstances not only as an effort to override particular substantive and procedural norms, but as an encroachment on the sovereignty of foreign nations.

27. F. Hoffmann-LaRoche Ltd. v. Empagran, S.A., 542 U.S. 155 (2004) (antitrust law); Morrison v. Nat'l Austl. Bank Ltd., 130 S.Ct. 2869 (2010) (securities law). 
is therefore part of the backdrop against which today's animosity to class actions must be viewed.

Another means by which U.S. class action practice was exported to Europe was the expansion into Europe of American plaintiffs' firms. Starting in the late 1990s, some of these firms began establishing offices in Europe, whose primary occupation was cultivating local claimants that could participate in U.S.-based class actions. ${ }^{28}$ In doing so, they brought into European territory a set of lawyering practices that were inconsistent with local norms. Throughout most of Europe, the litigation funding models that support class actions, which are permitted under U.S. rules of professional responsibility, are viewed as unethical, contrary to public policy, or both. In the United States, the default rule is that each party bears its own litigation costs, including attorneys' fees. In addition, in most types of lawsuits, attorneys are permitted to advance the ordinary expenses of litigation and to recover them, along with their own fees, in the form of a contingency payment. ${ }^{29}$ These rules protect plaintiffs from the risk of liability for fees in the event that their claims are unsuccessful. They thus remove cost barriers that might otherwise leave plaintiffs unable to bring meritorious claims; however, they also increase the possibility of unmeritorious litigation. Most European countries strike this balance differently: the default fee rule is "loser pays," and pure contingency payments are not permitted. U.S. rules also permit certain devices that support class actions in particular. The "common fund" doctrine, for instance, maintains that attorneys' fees for the entire plaintiff class can be paid out of a settlement or judgment, rather than borne on a more traditional contract-fee basis by the representative plaintiff. ${ }^{30}$

These cost rules make class actions viable. Under a traditional fee arrangement, class actions in which the claim of each individual plaintiff is small would not be sustainable, as no potential representative plaintiff would agree to bear the related costs - and no attorney would accept the burden of contracting with each class member individually. ${ }^{31}$ From the European perspective, however, they appear to invert the client-attorney relationship, such that it is the attorney

28. See discussion in Jeremy Fleming, Class Traction, 75 Eur. Law. 34, 37 (2008), and Louis Solomon, Born in the USA, 76 Eur. Law. 3 (2008) (both describing the activities of American class action firms in Europe).

29. See Rules 1.8(e)(1) and 1.5(c) of the Model Rules of Professional Conduct.

30. Boeing Co. v. Van Gemert, 444 U.S. 472, 478-81 (1980). For a study of comparative funding models, see The Costs and Funding of Civil Litigation: A Comparative Perspective (C. Hodges, S. Vogenauer and M. Tulibacka eds., 2010).

31. See Samuel Issacharoff, Group Litigation of Consumer Claims: Lessons From the U.S. Experience, 34 Tex. Int'l L. J. 135, 148-49 (1999) (discussing these funding mechanisms and their utility in class actions). 
rather than the class members who makes decisions about the legal claims, and, often, who receives the only substantial compensation from a settlement or judgment. ${ }^{32}$ Countries not eager to embrace such a system were understandably dismayed when U.S. firms opened up shop in order to serve local clients under these practices. ${ }^{33}$

In these ways, the imposition of class action values upon European countries - by U.S. courts, in including European claimants in regulatory actions, and by U.S. lawyers, in establishing practices there - contributed to the climate of antagonism toward the American system.

\section{CONSEQUENCES FOR REGULATORY REFORM}

Having recognized the manifestation of this antagonistic attitude toward the U.S. class action system, and some of its sources, we turn to the next question: is it harmful? Both Europeans and Americans might be indifferent to this particular antagonism - whatever the climate, European states will continue with their reform efforts and will adopt whatever form of group litigation is viewed as most effective and appropriate locally. But in my view the antagonism is harmful, for three principal reasons.

First, there really are valuable lessons to be learned from the long U.S. experience with class actions. Those lessons do not lie in the generalities of the American system - in the fact that class actions can be used to achieve stronger private enforcement of regulatory law, or that certain litigation financing structures will permit the development of a robust class action practice. Rather, they lie in the specifics of how that system has been implemented over time, and how it has evolved through efforts to address precisely the harms that worry current European reformers.

The procedural law governing U.S. class actions has been far from static. Since its adoption in modern form in 1966, that law has been repeatedly refined in an effort to maintain the regulatory benefits that class actions provide while mitigating the risks of their abuse. Adjustments to the system have included the enhancement of the courts' managerial role in reviewing and approving settlement proposals, as well as rule revisions slowing down the class certification process, which had been criticized as insufficiently rigorous and thus too

32. For a discussion of the centrality of this view of the lawyer-client relationship, see Rex $R$. Perschbacher, Lawyers and Ethical Issues/Considerations in Cross-Border Class Action Litigation, 2004 Mich. St. L. Rev. 735 (2004).

33. This situation was not improved by publicity surrounding the 2006 indictment of Milberg Weiss, a major U.S. plaintiff' firm, for paying investors kickbacks to serve as lead plaintiffs in class action securities litigation. 
plaintiff-friendly. ${ }^{34}$ Additional rules restructured the framework within which courts consider the appointment of class counsel, and enhanced judicial control over the award of attorneys' fees. ${ }^{35}$ In specific substantive areas, too, procedures were adopted to minimize the risks posed by class actions. In an amendment to U.S. securities laws, for example, a new process was put in place to select the lead plaintiff in securities class actions, in a way that would strengthen the role of the client, as opposed to that of the attorney, in managing litigation. ${ }^{36}$ And of course the Class Action Fairness Act of 2005 brought more sweeping changes by shifting a large proportion of class actions out of state courts and into federal courts, in order to stem perceived abuse of class litigation. ${ }^{37}$ Finally, in addition to these forms of legislative amendment, many judicial decisions over the years - on issues including standing, pleading requirements, and the standards for summary judgment have tuned the balance between plaintiffs' ability to bring class actions and the need to protect defendants from non-meritorious litigation. ${ }^{38}$

I recite this history not to argue that the United States has arrived at the point of perfect design for class litigation - because it quite clearly has not - but rather to argue that if one were trying to learn something from the U.S. experience, this is where one's attention should be. An atmosphere of hostility towards the U.S. system interferes with this kind of analysis. ${ }^{39}$ In a climate in which it is acceptable simply to reject the class action system in its entirety as "toxic," the likelihood of learning anything meaningful is low.

Second, as the antagonistic attitude is expressed in other countries, particularly by courts and regulators, it generates a response. That response may take the form of a retreat from conflict, which, paradoxically, may diminish the effectiveness of cross-border regulation.

34. These revisions were part of a series of changes made in 2003. See generally Fed. R. Civ. P. 23, Advisory Committee Notes (discussing these and other amendments to Rule 23 of the Federal Rules of Civil Procedure, governing class actions).

35. Id.

36. Private Securities Litigation Reform Act of 1995, Publ. L. No. 104-67, 109 Stat. 737 (1995).

37. Class Action Fairness Act of 2005, Pub. L. No. 109-2, § 2(a)(4), (b), 119 Stat. 4, 5 (codified at 28 U.S.C. $\S 1711$ (2006)).

38. In one recent decision that tightened pleading requirements, the Court specifically noted the desire to mitigate the "discovery abuse" that sometimes occurred in class actions. Bell Atlantic Corp. v. Twombly, 550 U.S. 544, 557-560 (2007). For a description of this sort of balancing process in the context of antitrust class actions, see Stephen Calkins, Summary Judgment, Motions to Dismiss, and Other Examples of Equilibrating Tendencies in the Antitrust System, 74 Geo. L.J. 1065 (1986).

39. For a similar view, see Tobias Krätzschmar, Der deutsch-amerkanische Rechtsverkehr - mehr als ein "Justizkonflikt," in Balancing of interests: Liber amicorum Peter Hay zum 70. Geburtstag 243-44 (2005). 
In my view, this is now occurring in the United States. In recent decisions, the U.S. Supreme Court has recognized other countries' disapproval of various aspects of our system. In a securities decision issued in 2010, for instance, the Court noted that

"[l]ike the United States, foreign countries regulate their
domestic securities exchanges and securities
transactions occurring within their territorial
jurisdiction. And the regulation of other countries often
differs from ours as to what constitutes fraud, what
damages are recoverable, what discovery is available in
litigation, what individual actions may be joined in a
single suit, what attorney's fees are recoverable, and
many other matters." 40

The Court went on to note that amicus briefs had been filed by a number of foreign governments, including Australia, the United Kingdom and France, and that the briefs "complained[ed] of the interference with foreign securities regulation" that our courts' application of U.S. securities laws abroad would produce.41 Partly on that basis, it concluded that the United States should focus on its own regulatory interest, by applying its laws only to transactions taking place within its own securities markets, in order to avoid engendering this kind of interference and conflict.

In a similar case in the antitrust area, the Supreme Court stated that

"Congress might have hoped that America's antitrust laws, so fundamental a component of our own economic system, would commend themselves to other nations as well. But, if America's antitrust policies could not win their own way in the international marketplace for such ideas, Congress, we must assume, would not have tried to impose them, in an act of legal imperialism, through legislative fiat." 42

As these decisions reflect, the U.S. Supreme Court understands that in cases of conflict, other countries actively resent the exportation of U.S. domestic norms through the vehicle of class action litigation. At

40. Morrison v. National Australia Bank Ltd., 130 S.Ct. 2869, 2885 (2010).

41. Id. at 2886 .

42. F. Hoffmann-LaRoche Ltd. v. Empagran, 542 U.S. 155, 169 (2004). 
one level, this is a very positive development, as the Supreme Court is recognizing the international implications of its decisions and taking those implications into account. Yet retreating in the name of comity and cooperation to a system in which each nation looks only at what happens within its own borders may in the end undermine effective global regulation. It is clear today that each country's "domestic" interest extends beyond transactions that take place in its markets. In the case of conduct that affects multiple jurisdictions simultaneously, such as global price-fixing, the fact that some countries do not regulate their markets effectively means that even if others do - imposing fines or extracting damages awards as the result of transactions occurring in our markets - the actors may still realize net gain from their conduct. ${ }^{43}$ If that is the case, such activity will continue, imposing ongoing private enforcement costs within the regulating jurisdictions. Thus, the local domestic interest includes an interest in adequate levels of global deterrence. In addition, all countries surely have shared concerns regarding the need for effective global regulation. Consider for example the very common situation in which an act of fraud affects both a group of U.S. investors who transacted within the United States and a group of foreign investors who transacted on a foreign exchange. There may be efficiencies to be gained by centralizing legal proceedings in order to avoid duplicative litigation in multiple jurisdictions. In other words, our national regulatory interests coincide with and overlap with the interests of other nations, in addition sometimes to conflicting with them. The hard work to be done in addressing cross-border conduct requires engagement with those messy relationships. If an attitude of antagonism toward our system causes our courts simply to disengage from that work, the antagonism is indeed problematic.

Third, and finally, I return to the point from which I started. All nations are currently working to develop global regulatory strategies, as it is clear that global economic misconduct cannot be adequately regulated by a patchwork of individual national legal systems. Thus, in addition to what is happening within European systems, or within the U.S. system, there is the broader task of establishing and refining multilateral regulatory initiatives - whether in the form of harmonized substantive rules or cooperative public enforcement strategies. That work can be successful only if it builds on the foundation of a thorough and contextual understanding of the very different legal, procedural,

43. A group of economists made this argument as amici curiae in the Empagran antitrust litigation. See discussion in Hannah L. Buxbaum, Transnational Regulatory Litigation, 46 Va. J. Int'l L. 251, 259-60 (2006). 
and cultural norms observed in different countries. ${ }^{44}$ An attitude of antagonism that simply rejects other legal systems interferes with the development of that understanding. It fosters reliance on anecdotal information - on the big cases, the dramatic examples, and the worstcase scenarios - rather than on empirical reality. Here, the question is not merely a narrow instrumental one (as a country considers adopting class action procedures, what, and under what circumstances, can it learn from a more established system?) but a much broader one about how to establish the conditions under which effective regulation of global business can be achieved.

The manner in which legal systems address the hard issues, the ones that create real conflict among different regimes, has consequences for the culture of global regulation generally. Today, when other countries are interested in something at least resembling U.S. class actions, there is a moment of possibility when we might seize a difficult issue and use it to improve the level of understanding and cooperation surrounding private enforcement generally. Doing that will involve examining not just the procedural device of aggregate litigation, but the political economy of regulating through aggregate litigation. It will involve analyzing the embeddedness of class actions in the larger regulatory framework of individual nations today, as well as the way in which class actions might interact with the public regulatory structures developing at the international level.

That is an important project. But it will be done effectively only when we set aside patterns of conflict and antagonism and focus instead on the shared imperative of improving cross-border regulation.

44. This is of course precisely the project recognized and undertaken by Professor Stürner and his colleagues in preparing the ALI/UNIDROIT Principles of Transnational Civil Procedure. 


\section{.}

